\title{
Herpes Simplex Virus 1 IgG Antibody Measurement
}

National Cancer Institute

\section{Source}

National Cancer Institute. Herpes Simplex Virus 1 Ig G Antibody Measurement. NCI

Thesaurus. Code C96666.

The determination of the amount of Herpes Simplex virus $1 \mathrm{IgG}$ antibody present in a sample. 